\title{
LUXURY REDEFINED: A CASE STUDY OF THE ANANDA-IN THE HIMALAYAS, UTTARAKHAND, INDIA
}

\author{
Rahul Mehta \\ Amity Institute of Design, Amity University Haryana, India \\ Email: rahulmehtaarchitects@yahoo.com; rmehta@ggn.amity.edu
}

Article History: Received on $02^{\text {nd }}$ March, Revised on $25^{\text {th }}$ May, Published on $30^{\text {th }}$ May 2020

\begin{abstract}
Purpose of study: The purpose of this case study is to comprehend how the allure of a hotel plays a significant role in a tourist's goal of decision, desires for the fulfillment, aims to return to, an impression of advantages and inspirations, the measure of cash spent, and the duration of the stay.
\end{abstract}

Methodology: This study employed a descriptive case study of the Ananda-In the Himalayas, focusing on understanding the various design perspectives of this place with the different amenities provided by it, making it one of the top luxury destination resort.

Main Findings: According to this study, the destination, amenities provided, and hospitality of this place make it the top wellness resort. The place is a beautiful combination of design architecture, elegant lighting, and has a connection with nature, which makes it attractive for its visitors.

Limitations: The study has only been done of one restaurant with a proper literature review. Therefore, the results of the study may be applied with caution outside the scope of the study.

Social Implications: Although this case study is way more descriptive than predictive, the results can help researchers from varied realms of hospitality and tourism with valuable insights regarding the direction of future publishing efforts in this field. This study may also help researchers to understand the design concepts and features required for a luxury destination spa resort.

Originality: This place has not been studied with a perspective of this kind, and therefore, not much literature is there, especially on this resort. However, this study will bridge the gap between the design features, destination, and the hospitality provided by the resort. This study can be used as a benchmark for other studies, which will be done based on both tourism and hospitality, and in today's era, both are becoming more demanding, more varied, and more qualitative.

Keywords: Resort, tourism, hospitality, luxury, rejuvenation, Ananda-in the Himalayas

\section{INTRODUCTION AND LITERATURE SURVEY}

According to Brey (2011), a resort can be defined as a full-service lodging facility that provides access to or offers a wide range of amenities and recreational facilities to emphasize the leisure experience. Resorts are a source of leisure experience that also offers business services such as meetings and conferences in a vacation environment (Brey, 2011), The location and destination attractiveness of a resort plays a vital role in the selection of the resort by the tourists. As Mayo and Jarvis (1981) defined, destination attractiveness is the "perceived ability of a destination to deliver exclusive benefits. Henkel et al. (2006) and Reitsamer et al. (2016) have studied the role of destination attractiveness and destination attachment. They have reported that the attractiveness of a destination makes a significant contribution to the tourist destination choice, satisfaction expectations, revisiting intentions benefits offered, and duration of stay. According to Vengesayi (2003), the amenities offered by a resort to the tourists apparently make is more attractive and perceived over others.

As studied by Prayag \& Ryan. (2011), tourists' feeling of belongingness to a destination and their destination attachment can enhance destination management organizations (DMOs) by the kind of services the respective destination offers. Creating a place that can be a source of attachment to tourists will be more advantageous and attractive (Yuksel et al., 2010). The literature review has revealed the significance of destination attachment which may include travel motivation (Prayag et al., 2014), the credibility of destination source (Veasna et al., 2013), destination image (Prayag \& Ryan, 2011), the involvement of tourists' (Gross \& Brown, 2008) and previous experience of the tourists' (Kyle et al., 2004). As studied by Prayag \& Ryan (2011) and Veasna et al. (2013), that destination attachment is caused by a set of destination-specific resources and assistance that DMOs can facilitate and control.

The majestic Himalayas Mountain Ranges located at the north side of India, which separates the Indian Subcontinent with the Tibetan region is endowed with outstanding natural beauty and endangered. Endemic animals of Himalaya make it one of the most visited tourist attraction of the country. Shri Ashok Khanna, the founder, and managing director of the Anandain the Himalayas spa resort has named it since it embodies the spirit and ethos of what he wanted to offer to his guests. He has strong beliefs in holistic wellness for the mind, body, and soul, which could be delivered through being at Ananda. Due to which this resort is situated in the foothills of the Himalayas, the birthplace of Yoga, where people have visited for centuries to be healed and to find rest and rejuvenation. 
Based on the literature review of a number of articles (Becker, 2009; Curtis, 2001; Cohen \& Bodeker, 2008; $\underline{\text { Heide \& }}$ Gronhaung, 2009) which has discussed the appropriate design features for luxury destination resorts, the critical design features of the Ananda-In the Himalayas has been studied and monitored how it has promoted this hotel to a luxury destination spa resort. For instance, some luxury hotels' design features include exotic destination, spacious, high-quality artworks, landscaping, elegant lighting that feels warm and inviting, quality and appearance of amenities, and spacious bathrooms with bathtubs lavatories. These key design features make guest's stay more comfortable and memorable. The purpose of this case study is to explore Ananda-In the Himalayas and to study the various essential attributes of this luxury destination resort.

\section{METHODOLOGY}

This study has employed a descriptive case study of the Ananda-In the Himalayas, focusing on understanding the various design perspectives of this place with the different amenities provided by it, making it one of the top luxury destination resort.

Ananda-In the Himalayas is used as the setting of the research. The reason why Ananda-In the Himalayas is chosen as the main focus of this case study is that it is a five-star Luxury Destination Spa Resort that is worth to conduct a more in-depth study as it has been ranked as the No. 1 Destination Spa in the World by Condé Nat-Reader's Choice Awards (USA \& UK) for the year 2019 and also as the Condé Nast Traveler, India-Reader's.

Travel Award for the favorite Destination Spa. It has also received the Best resort award by Zee Business awards in the year 2018 and is a recipient of many prestigious awards in the previous years, as also mentioned at the official website of Ananda.
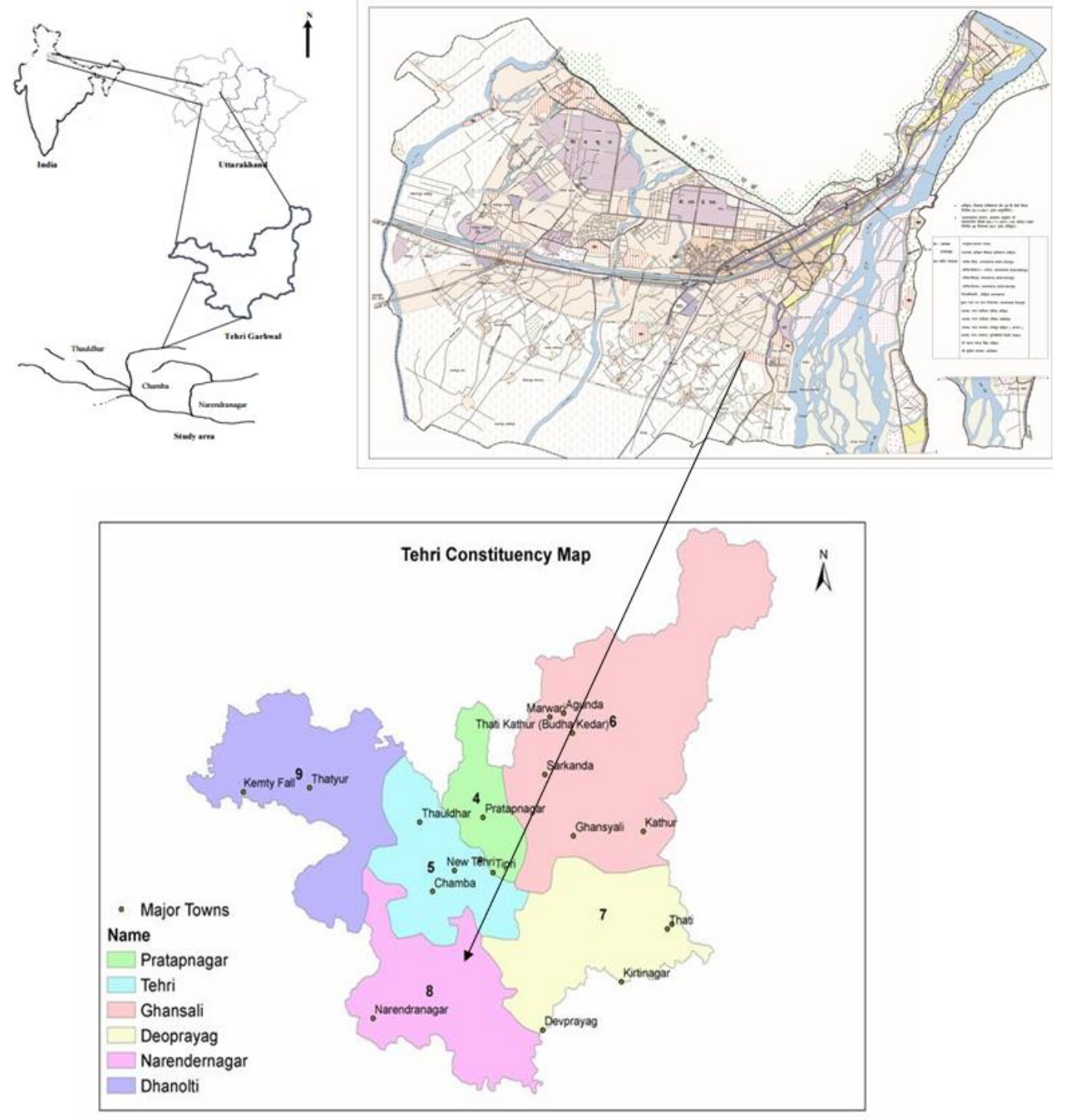

Figure 1: The Tehri constituency map(Uttarakhand Tourism development master plan 2007-2022; Uttaranchal Travel Guide 2008) 


\section{LOCATION ANALYSIS}

Narendra Nagar district Tehri Garhwal, Uttarakhand, on the northern aspect at elevations ranging from $1000 \mathrm{~m}$ to $2000 \mathrm{~m}$.

Geographical location and physiography: The area falls between sub- tropical to temperate Zones which lie between 780 $12^{\prime} 30^{\prime \prime}$ to $78018^{\prime} 20^{\prime \prime}$ E longitudes and $30016^{\prime} 14^{\prime \prime}$ and $30021^{\prime} 30^{\prime \prime} \mathrm{N}$ latitudes.

Rainfall: The area falls between sub-tropical to the temperate zone, with an average annual rainfall of $1240 \mathrm{~mm}$. Most of the rain (about 70\%) in the region occurs from July to September when the South-West monsoon is active. The number of rainy days varies from 70 to 80 days in a year.
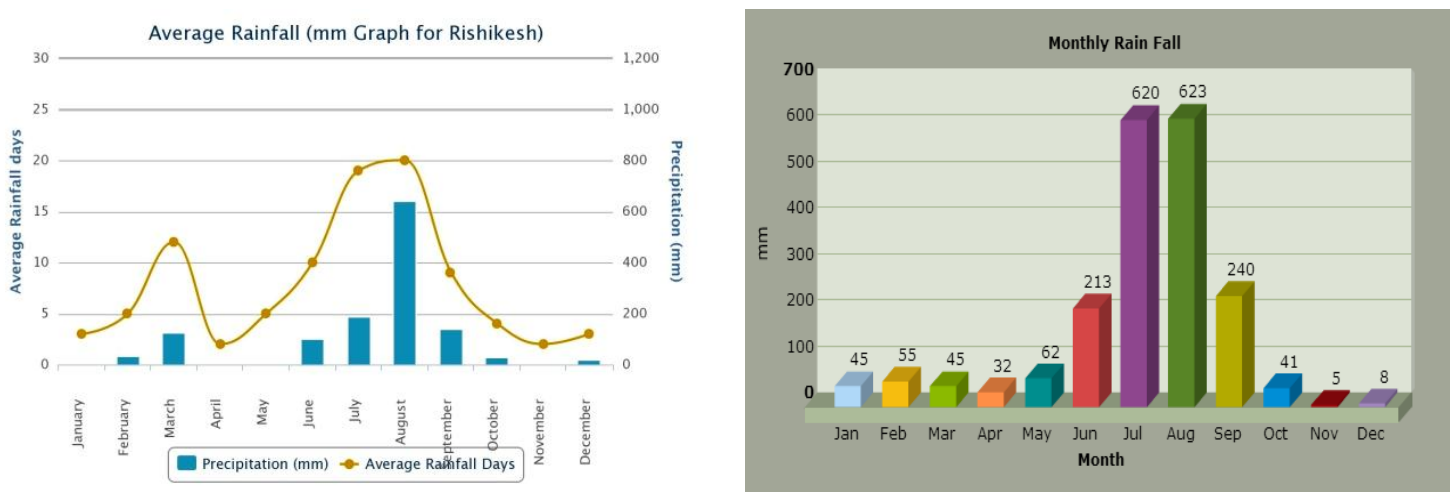

Figure 2: Average and monthly rainfall in Rishikesh (Uttarakhand Tourism development master plan 2007-2022; Uttaranchal Travel Guide 2008)

Wind: The most prominent wind direction during the season is northeast in the morning and west to northwest in the evening.

\section{RESULTS/DISCUSSION}

In the foothills of Himalayas; overlooking the sacred Ganges this beautiful and luxurious "Ananda-In The Himalayas", which is surrounded by Sal trees spread over in acres. This is set in the Garwal terrain grounds of a Maharaja's palace high above the Ganges of Uttarakhand built by the maharaja of Tehri garwal in 1911. The picturesque palace of the Maharaja of Tehri-Garhwal at $1650 \mathrm{~m}$ above sea level, with its very distinctive style, has then been modified, converted, and added to this place. The palace was built more in the Moorish architecture style with some tints of Italian Renaissance columns being coupled with Gujarati / Rajasthani jarrokhas, which extend into the Viceregal Palace. There is an existence of composite structure in the Viceregal Palace i.e.it is not much modified. It has Indian Bijapuri arches on the outside which are coupled with Art Deco in the interiors. It was further converted into a resort spread in 100 acre in 2000 with an enchanting and exciting environment.

The resort is eco-friendly created at a mountain terrain where Special care has been taken so that the wooded areas of the property remain intact by keeping all trees at their places. To enhance the environment and beauty of the resort additional shrubs, plants and trees have been planted. In some places, even some courtyards and niches are built around the trees to retain them.

In addition to this, upmost care has been taken to maintain the original decorum and magnificence of the palace for which and its surrounding areas are not tampered. Keeping in mind that the guests enjoy their stay and are comfortable at the resort, modern technologies have been used keeping in mind that the palace is restored with its former glory.

The master plan of the resort was developed in such a way that the entry starts from the Palace grounds which go through an extravagant gate towards a driveway which focuses on the Palace façade. No petrol/diesel vehicles are allowed on the resort premises, ecofriendly transportation such as electric carts are used for internal transportation for over an area of 30 acres.

The hotel's design is divided into the following sections:

- Luxury Villas

- The entrance and reception at the Palace

- The sits and spa complex coupled with an Amphitheatre for entertainment and concerts of classical music and chanting of mantras.

- Spa

- Lounge and Restaurant

- Guest Residence 

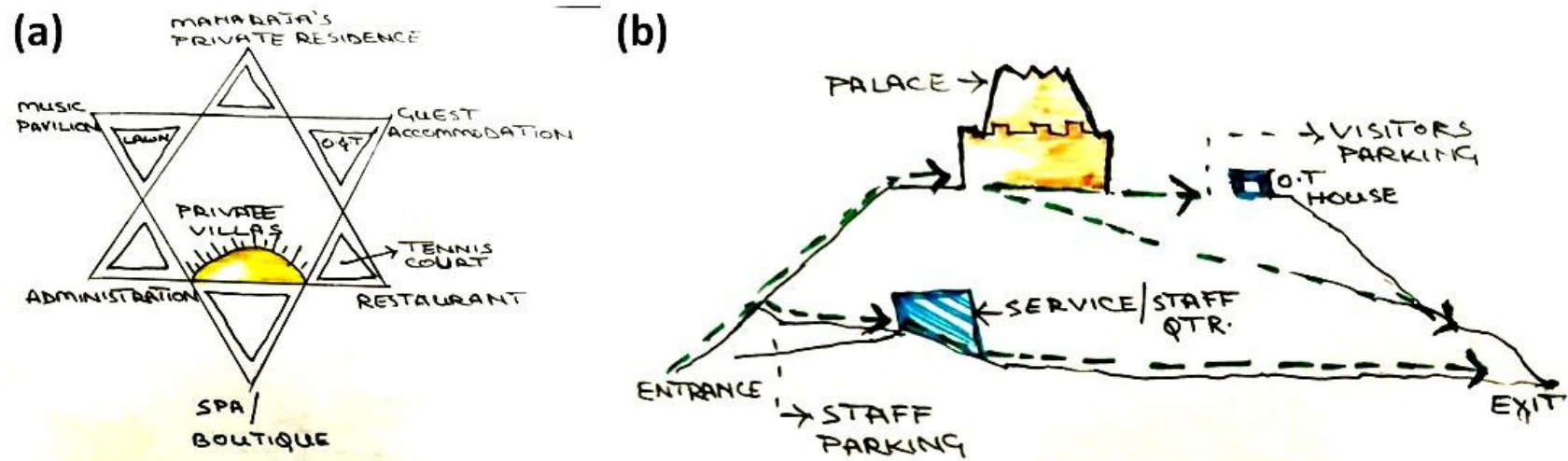

Figure 3: (a)Design development planning concept of the Ananda-in the Himalayas (b) Terrain site elevation

The architectural design \& planning of the resort was performed as per the natural terrain of the land. Stepped architecture is used in building up the guest room block as it's built on the slope. Similar to the cottages and buildings in the nearby hamlet of Narendra Nagar, terracotta roof tiles have been used, similar to the ones used in cottages and buildings in the nearby hamlet of Narendra Nagar. Modern facilities have been built with indigenous materials wherever possible.

\section{Façade treatments}

The building has been provided a visual, and perhaps structural, framework. Modulate façades with breaks, setbacks, and other elements. Windows are provided with historic guidelines \& proportions, Windows on the ground floor are larger than windows on upper floors.

\section{Ananda Spa}

The spa is spread over in an area of around 24,000 squares. There are 24 treatment rooms with specialized areas offering Ayurveda, Oriental and European systems of holistic health with the help of 79 different body and beauty treatments. Temperature controlled pool and a 16-station life-cycle gymnasium are also offered by the Ananda Spa.

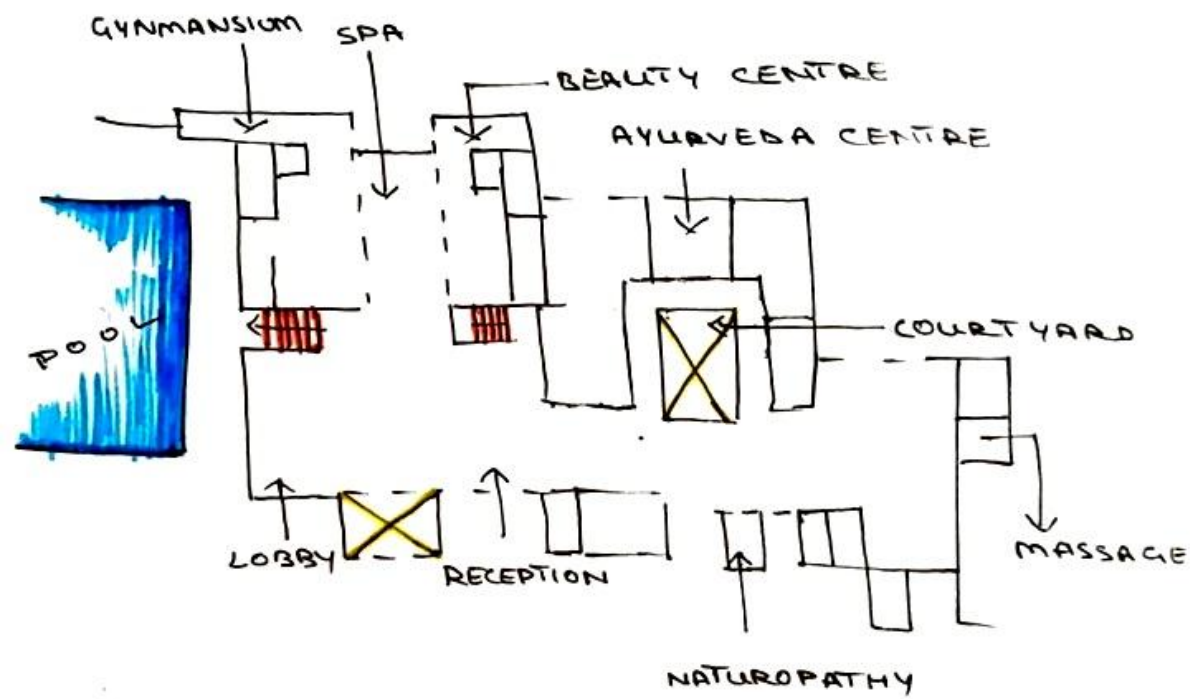

Figure 4: Ground floor planning of amenities for spa and pool area

Table 1: The types of rooms and facilities provided at the Ananda in the Himalayas Facade View

\begin{tabular}{|l|l|c|}
\hline Types of Rooms & Facilities & Number of Rooms \\
\hline Treatment room & $\begin{array}{l}\text { Separate beauty treatment salon, Kama suite for a couple with } \\
\text { Jacuzzi, sauna \& massage. }\end{array}$ & 20 \\
\hline Relaxation room & $\begin{array}{l}\text { Hydro-therapy facilities: steam, sauna, Jacuzzi, showers, foot } \\
\text { bath, changing rooms, etc. }\end{array}$ & 4 \\
\hline Consultation room & $\begin{array}{l}\text { Outdoor heated lap pool \& Jacuzzi, gym:16 station life fitness } \\
\text { gym with cardio, strength training, etc. }\end{array}$ & 4 \\
\hline
\end{tabular}



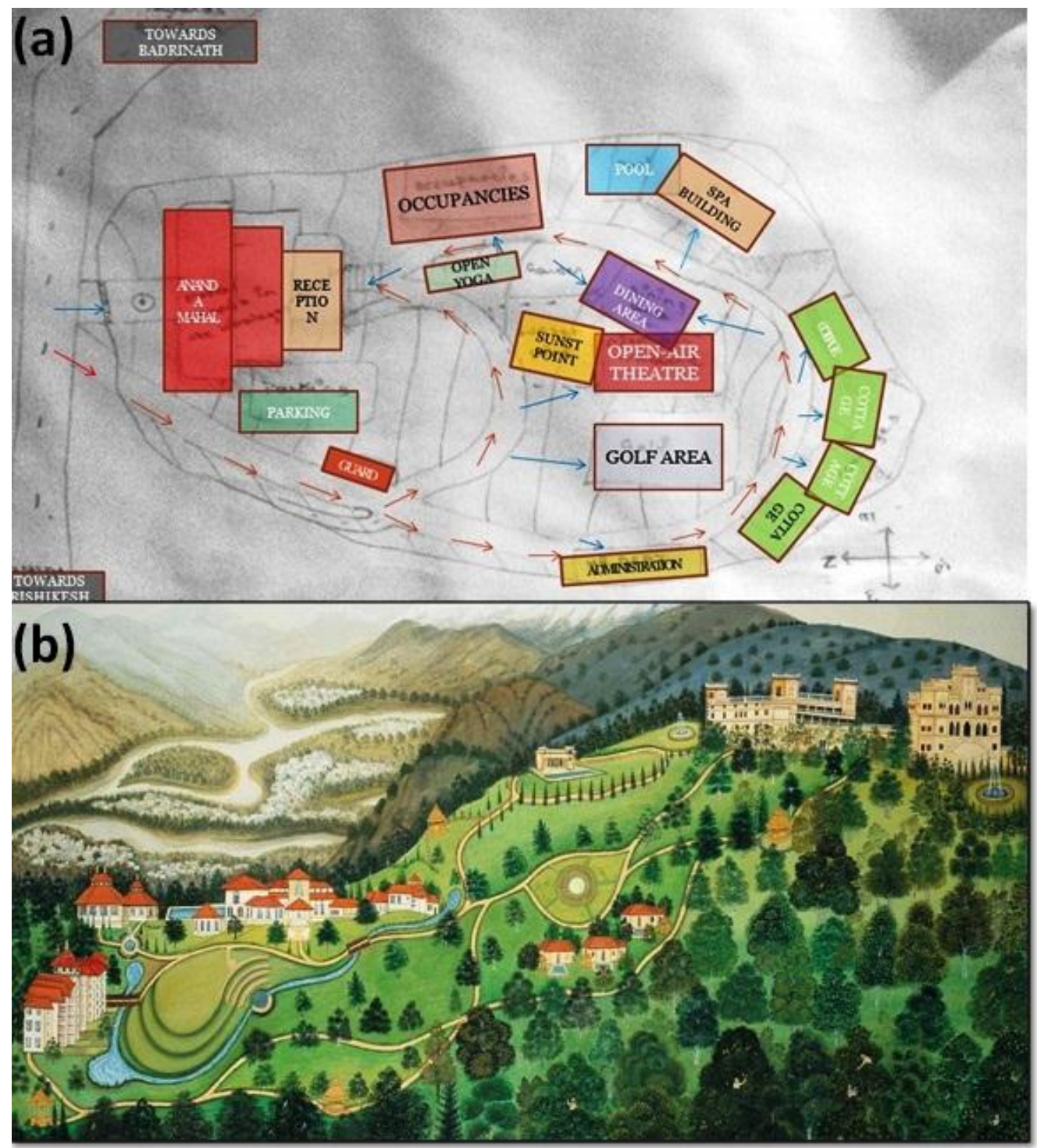

Figure 5: (a) Ananda-in the Himalayas Site Plan (b) Ananda-in the Himalayas Site View [for (b) Picture courtesy: Official website of the Ananda]

\section{Types of rooms:}

- $\quad$ Deluxe rooms -70

\section{Area: $35 \mathrm{~m}$ sq.\& $45 \mathrm{~m}$ sq. / $484 \mathrm{ft}$ sq.}

These rooms have warm and elegant wooden floors with only essential furniture i.e. a walk-in closet, dressing area, and well-lit bathrooms.

- $\quad$ Deluxe Suites -3

\section{Area: 1800 sq. ft (2-bedroom villa) \& 1200 sq. ft (1-bedroom villa)}

It has two 2-bedroom villas and one 1-bedroom Cottage. Each one is elegantly designed and decorated with a living room, a pantry for the butler, a dressing room, and a huge bathroom featuring a private sauna with an unhampered view of the swimming pool. 

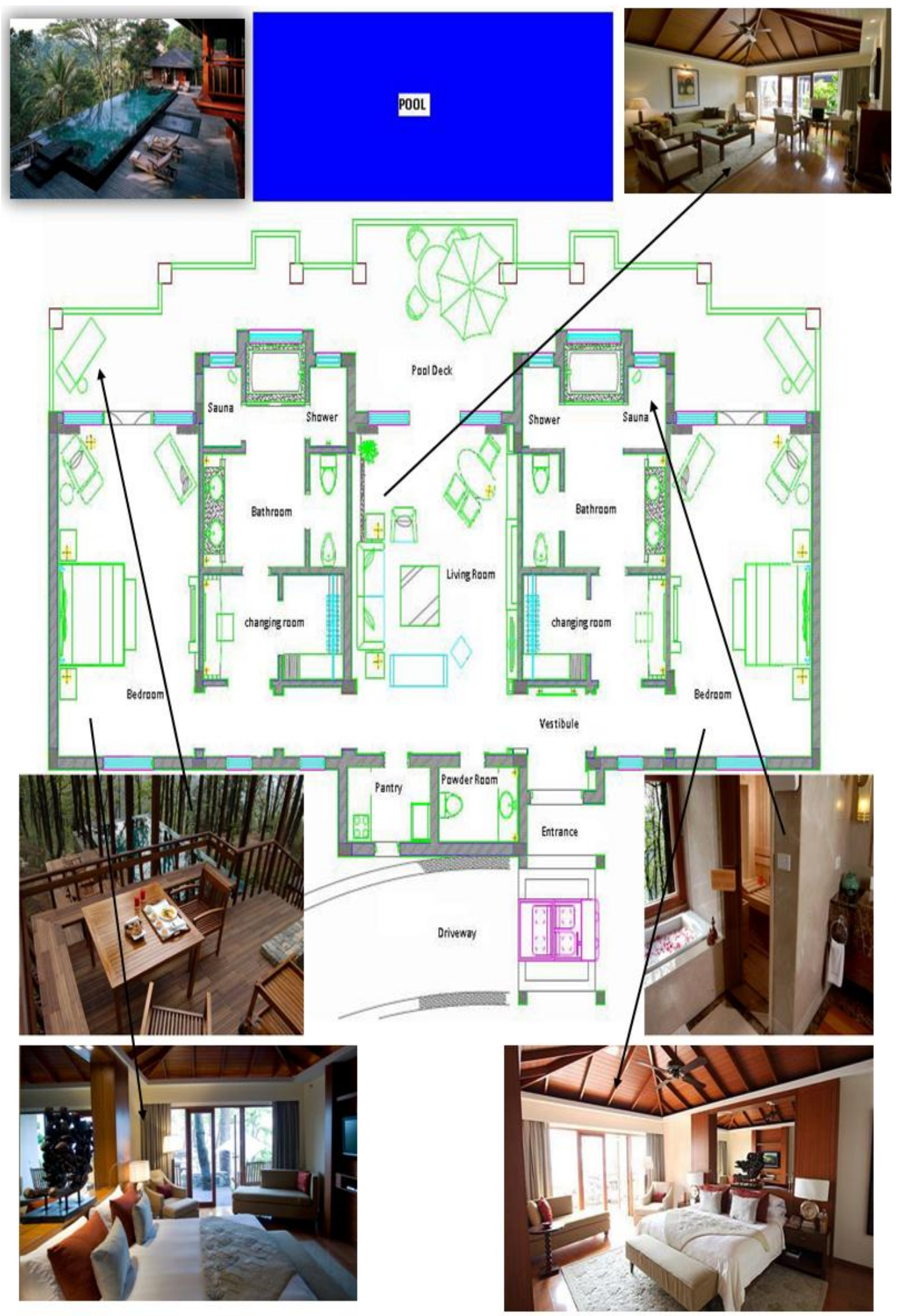

Figure 6: Cottage two-bedroom plan (1800 sq. ft.) 

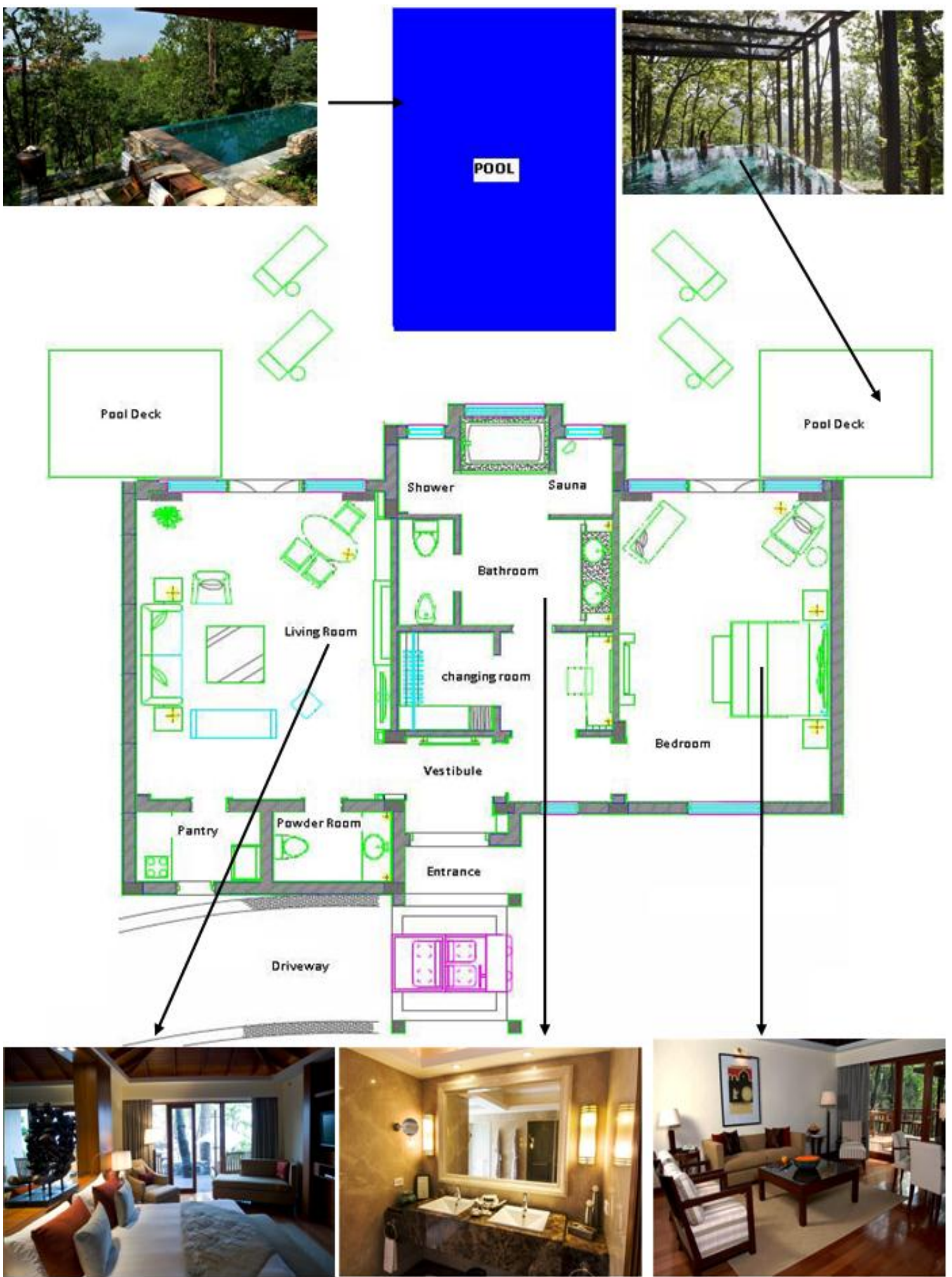

Figure 7: Cottage one-bedroom plan (1200 sq. ft.)

\section{AMENITIES AT ANANDA SPA RESORT AND NAME OF SERVICE UNIQUENESS}

Yoga Pavilion: A majestic open-air marbled floor shelter with gold leaf ceiling fresco, surrounded by a still and peaceful water pool at the south end of expansive palace lawn. The intimate setting excellent location to view the sunset and is ideal for individual instruction or private meditation.

Viceregal Hall: This hall is ideal for more active forms of yoga. A tranquil hillside garden is tucked just outside the valley's ridge- a perfect refuge for Himalayan tea after an invigorating yoga session or peaceful meditation. 
Board Room II: The board room is being glassed on four sides which have been done to have an impressive view of the mountains.

Winter Garden: This area overlooks a dense groove of Sal trees. The area has enchanting spiritual surrounding which makes it suitable for enhancing the yoga sessions.

Hill Theatre: This place offers a view of the foothills and palace.

The Pool: - The 40 Meters private pools are surrounded by a deck area equipped with comfortable lounge beds.

\section{INFERENCES:}

$\checkmark \quad$ All placing of blocks is well connected

$\checkmark \quad$ Built and open spaces, with the surrounding environment, are well maintained in all directions.

$\checkmark$ Cottages are well organized, with a private pool view of nature.

$\checkmark$ No vehicle movements are allowed inside the resort living a friendly environment.

$\checkmark$ Private sauna provided in all rooms.

$\mathrm{X}$ Block placing too far away.

$\mathrm{X}$ Entrance not well entertained.

\section{Actual Site photographs:}

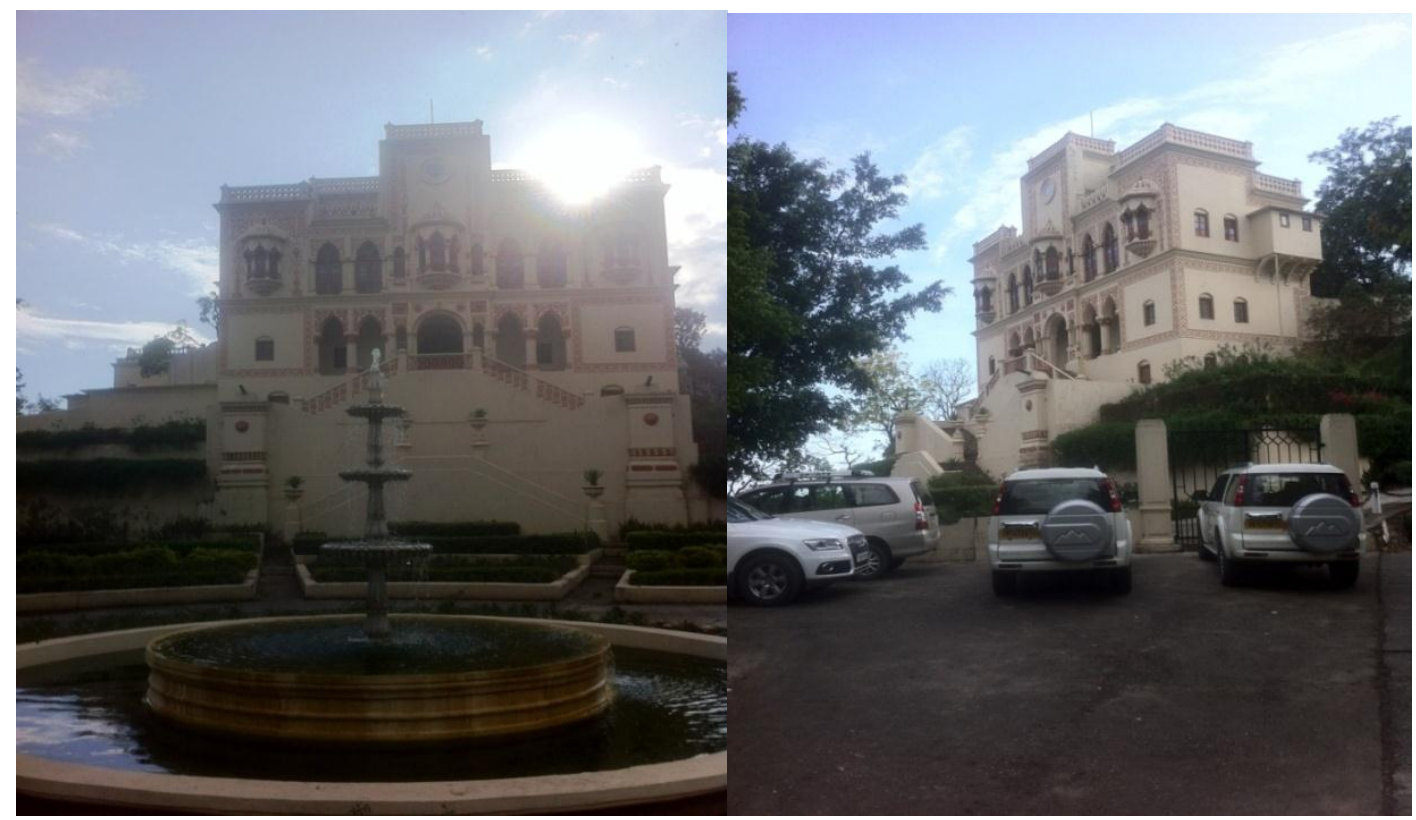

Figure 8: Ananda Mahal Front View

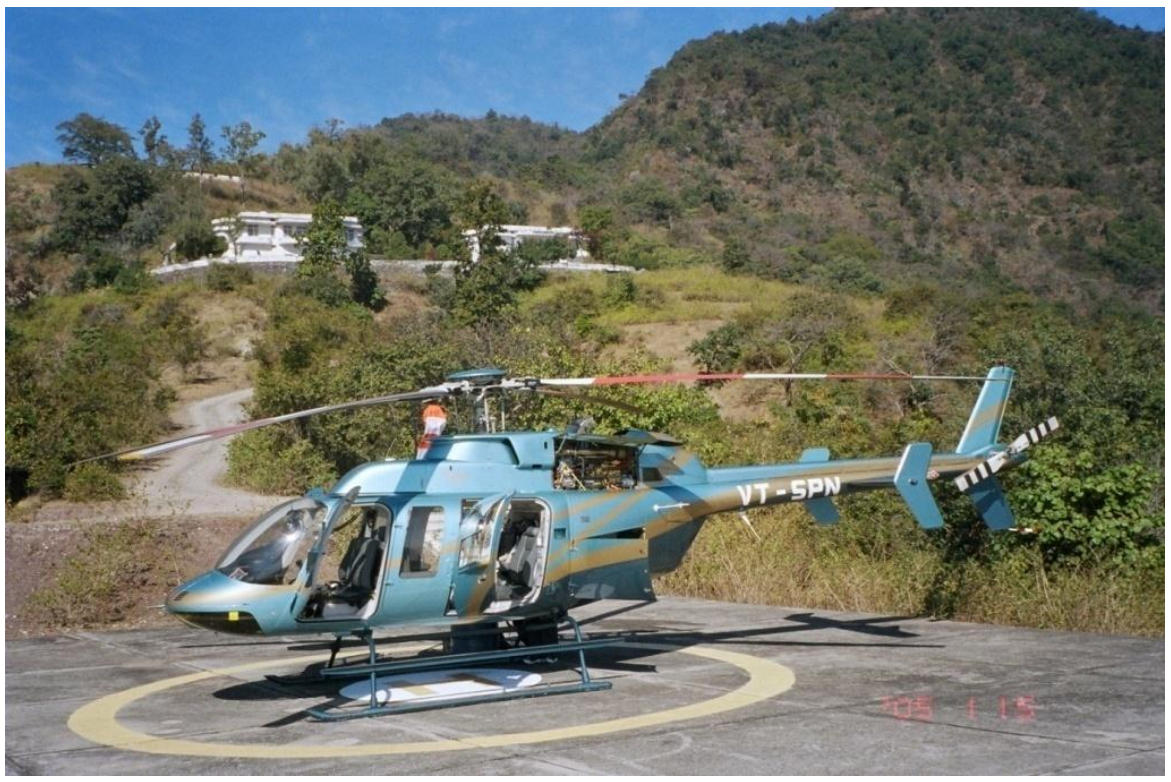

Figure 9: Helipad Area of the " Ananda-in the Himalayas" 


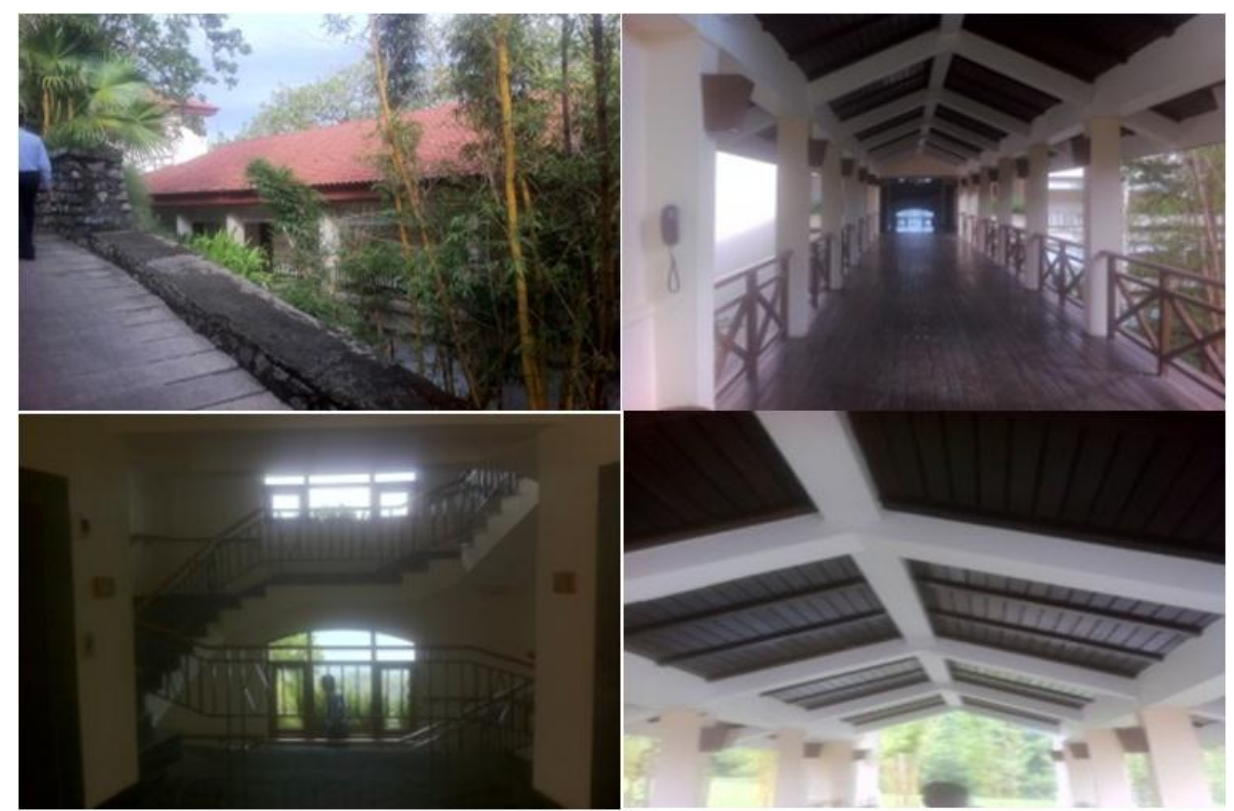

Figure 10: Ananda-In the Himalayas Occupancies View
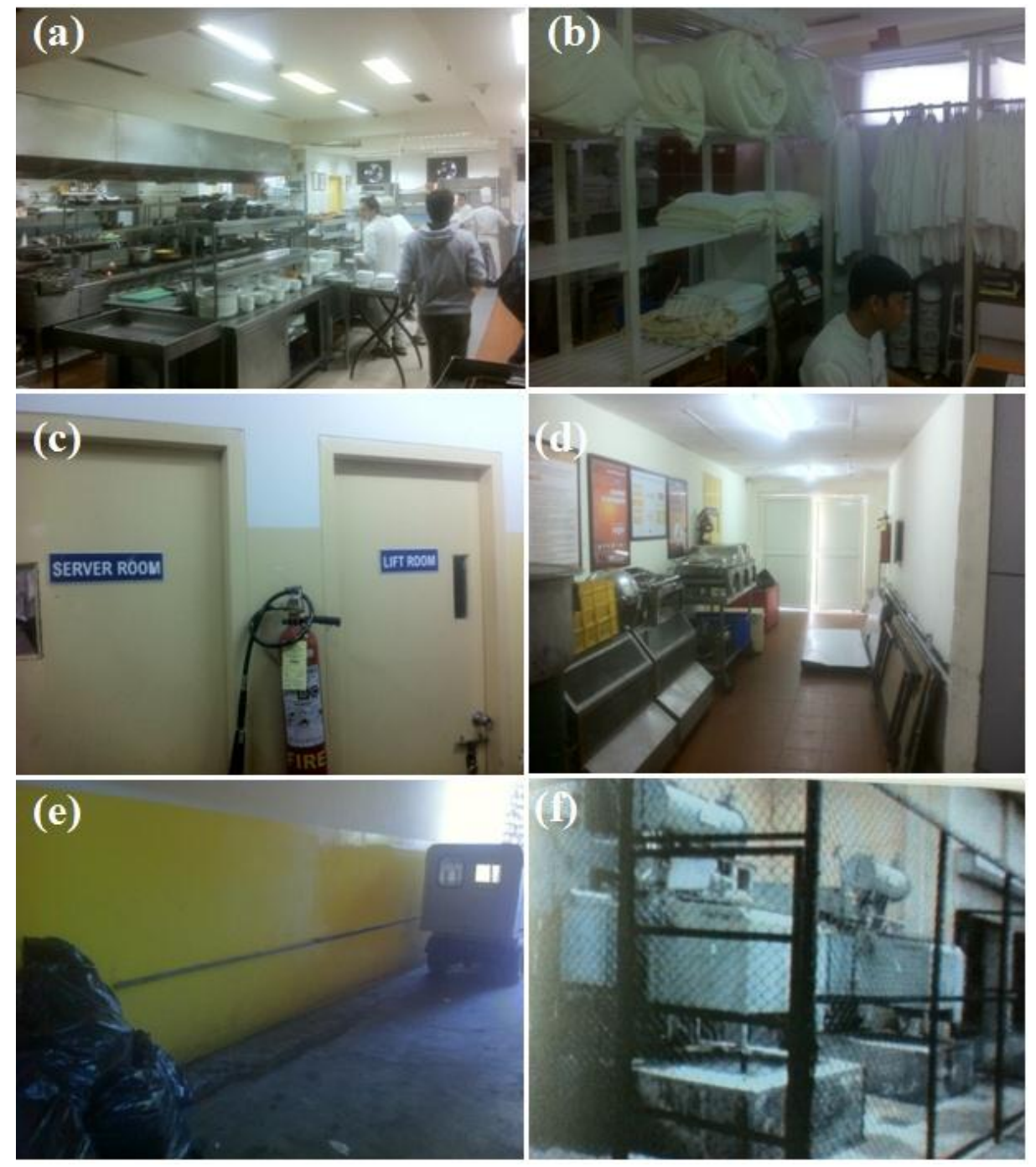

Figure 11: (a) Service Kitchen (150sq m) (b) House Keeping (25sq m) (c) Service Rooms (25sq m) (d) Catering Unit $(15 \mathrm{sq} \mathrm{m})(\mathbf{e})$ Garbage Area (f) HVAC 


\section{CONCLUSION}

This case study of the Ananda-In the Himalayas, Uttarakhand provides a better understanding of the design features of a luxury destination spa resort. This study is presumed to provide the first content analysis conducted to date that presents past research on luxury destination spa resorts. Although this case study is way more descriptive than being predictive, the results can help researchers and scholars from hospitality and tourism with valuable insights regarding the direction of future publishing efforts in this field. This paper may also help scholars understand the design concepts and features required for a luxury destination spa resort.

\section{REFERENCES}

1. Brey, E. T. (2011). A Taxonomy for Resorts. Cornell Hospitality Quarterly, 52(3),283290.https://doi.org/10.1177\%2F1938965510397537

2. Mayo, E. \& Jarvis, L. (1981). The psychology of leisure travel: Effective marketing and selling of travel leisure travel. Boston, MA: CABI Publishing.https://doi.org/10.1177\%2F004728758202000313

3. Henkel, R., Henkel, P., Agrusa, W., Agrusa, J. \& Tanner, J. (2006). Thailand as a tourist destination: Perceptions of international visitors and Thai residents. Asia Pacific Journal of Tourism Research, 11(3):269287.https://doi.org/10.1080/10941660600753299

4. Reitsamera, B.F., Brunner-Sperdin, A., Stokburger-Sauer N.E. (2016). Destination attractiveness and destination attachment: The mediating role of tourists' attitude. Tourism Management Perspectives . 19, 93101.https://doi.org/10.1016/j.tmp.2016.05.003

5. Vengesayi, S. (2003). A conceptual model of tourism destination competitiveness and attractiveness. Paper presented at ANZMAC Conference, Adelaide, Australia (1-3 December).

6. Prayag, G., \& Ryan, C. (2011). Antecedents of tourists' loyalty to Mauritius: the role and influence of destination image, place attachment, involvement, and satisfaction. Journal of Travel Research, 51 (3): 342356.https://doi.org/10.1177\%2F0047287511410321

7. Yuksel, A., Yuksel, F., \& Bilim, Y. (2010). Destination attachment: effects on customer satisfaction and cognitive, affective and conative loyalty. Tourism Management, 31(2): 274284.https://doi.org/10.1016/j.tourman.2009.03.007

8. Prayag, G., Hosany, S., \& Soscia, I. (2014). I feel attached: Motivation and tourists' emotions as antecedents of place attachment. Proceedings of the 43rd EMAC Conference 2014, Valencia, Spain, June 3-6, 2014.

9. Veasna, S., Wu, W., \& Huang, C. (2013). The impact of destination source credibility on destination satisfaction: the mediating effects of destination attachment and destination image. Tourism Management, 36: 511526.https://doi.org/10.1016/j.tourman.2012.09.007

10. Gross, M.J., \& Brown, G. (2008). An empirical structural model of tourists and places: progressing involvement and place attachment into tourism. Tourism Management, 29(6): 11411151.https://doi.org/10.1016/j.tourman.2008.02.009

11. Kyle, G., Graefe, A., Manning, R., \& Bacon, J. (2004). Effects of place attachment on users' perceptions of social and environmental conditions in a natural setting. Journal of Environmental Psychology, 24(2): 213225.https://doi.org/10.1016/j.jenvp.2003.12.006

12. Becker, E. J. (2009). The Proximity Hotel: A Case Study on Guest Satisfaction of Sustainable Luxury Environments, Masters Thesis, The University of North Carolina at Greensboro, Greensboro, NC.

13. Curtis, E. (2001). Hotel: Interior Structures, Wiley-Academy, West Sussex, Great Britain.

14. Cohen, M. \& Bodeker, G. (2008). Understanding the Global Spa Industry: Spa Management, Elsevier Ltd, Oxford, UK.

15. Heide, M. \& Gronhaung, K. (2009). "Key Factors in Guest's Perception of Hotel Atmosphere." Cornell Hospitality Quarterly, 50, (1), 29-43.https://dx.doi.org/10.1177/1938965508328420

16. Official website of Ananda. https://www.anandaspa.com

17. Uttarakhand Tourism Ministry. (2007-2022). Uttarakhand Tourism development master plan 2007-2022, final report.

18. Uttaranchal Travel Guide. (2008), pg. 35-42, $64 \& 78$. 